\title{
Newcastle Disease in White Pekin Ducks: Response to Experimental Vaccination and Challenge
}

- Author(s)
Nishizawa $\mathrm{M}^{1,2,3}$
Paulillo $\mathrm{AC}^{1}$
Nakaghi $\mathrm{LSO}^{1}$
Nunes $\mathrm{AD}^{1}$
Campioni JM ${ }^{1}$
Doretto Júnior L4
1 Universidade Estadual Paulista, Faculdade
de Ciências Agrárias e Veterinárias, Campus
de Jaboticabal, SP, Brasil,
2 Aluna do Programa de Pós-Graduação em
M edicina Veterinária da FCAV-UNESP,
Jaboticabal, SP, Brasil,
3ocente da Universidade M etodista do
Estado de São Paulo - UM ESP, São
Bernardo do Campo, SP, Brasil,
4 Laboratório de Referência Animal,
Campinas, SP, Brasil.

Mail Address

M Nishizawa
Rua Coronel Francisco Rodrigues Seckler, 43,
Vila Paulicéia
09693-050. São Bernardo do Campo, São
Paulo, Brazil
E-mail: marcianishizawa@yahoo.com.br

Keywords

Anas platyrhynchos, NDV carrier, Newcastle disease, Pekin duck, vaccination.

\section{ABSTRACT}

A total of 120 Pekin ducks were distributed at random into four experimental groups, vaccinated or not against New castle disease (ND): G1 (Ulster 2C strain), G2 (B1 strain), G3 (LaSota strain), and G4 (nonvaccinated group). At 60 days of age, all groups were challenged with a pathogenic ND virus (NDV) suspension, and a group of specific pathogen free (SPF) chicks (G5) was also inoculated. Cloacal and tracheal swabs from all birds were collected after six, 14, 20, and 30 days postchallenge for virus isolation. NDV was isolated in $100 \%$ of SPF chicks. Pekin ducks from all groups, vaccinated or not, did not show any ND clinical signs, demonstrating that these birds are not susceptible to ND clinical disease. In the control group (G4), the virus was isolated 20 to 30 days after challenge, suggesting their possible NDV carrier state. In the vaccinated groups, no virus was isolated. This demonstrates that vaccination of white Pekin ducks against NDV is important to reduce NDV shedding in the field.

\section{INTRODUCTION}

Newcastle disease (ND) remains one of the most important poultry virosis, with highly infectious capacity, affecting both domestic and wild birds. Routine vaccination combined with the sacrifice of affected birds have helped to control the very virulent disease caused by ND virus (NDV), classified as A vian Parainfluenzavirus type 1. Newcastle disease is one of the main sanitary barriers for the free trade of poultry and poultry products (Office International Des Epizootes, 1996). The disease is currently distributed world-wide in a large range of hosts, with 27 of the 50 orders of birds reported to be possibly infected by this agent (Kaleta \& Beldauf, 1988). One of the affected species is the white Pekin duck, which is commercially reared in several states of Brazil to produce meat.. How ever, to date, studies on health control of this poultry species are lacking. This study aimed at investigating the importance of the vaccination against Newcastle disease and NDV-carrier state of Pekin ducks.

\section{MATERIAL AND METHODS}

Experimental birds and management: $A$ total number of 120 dayold white Pekin ducks were distributed into four treatments of 30 birds each. Birds were housed in pens on litter, keeping a distance between treatment groups. Birds were designated to treatments, according to vaccination strain as G1 (Ulster $2 \mathrm{C}$ ), G2 (B1), or G3 (LaSota), and to treatment G4 (control group - not vaccinated). Birds were fed a balanced diet according to different growth phases. 
Nishizaw a M, Paulillo AC, Nakaghi LSO, Nunes AD, Campioni JM, Doretto Júnior $L$
New castle Disease in White Peking Ducks: Response to Experimental Vaccination and Challenge
Vaccines: Commercial live NDV vaccines (Ulster 2C, $\mathrm{B} 1$, and LaSota strains) were administered to each experimental group, as described by Paulillo et al. (1996). Birds were vaccinated at seven days of age, and revaccinated at 29 days of age with the same vaccine strain that was applied in the first vaccination. Vaccine titers were obtained by determining $50 \%$ of the embryo-infecting dose in embryonated eggs of specific-pathogen-free breeders at 8 and 10 days of incubation. Titers of live vaccine strains Ulster $2 \mathrm{C}, \mathrm{B} 1$, and LaSota were $7.15 \log _{10} / 0.1 \mathrm{~mL}, 7.2 \log _{10} / 0.1 \mathrm{~mL}$, and $7.35 \log _{10} / 0.1 \mathrm{~mL}$, respectively. Birds were vaccinated and revaccinated by ocular route.

Serology: Blood samples of white Pekin ducks were collected from seven to 60 days of age, at regular seven-day intervals. Nine samples from each group were collected on each day. Sera were inactivated at $56^{\circ} \mathrm{C}$ for 30 minutes, frozen, and stored at $-20^{\circ} \mathrm{C}$. Sera samples were submitted to inhibition of hemagglutination (HI) test, according to Cunningham (1971).

Challenge: At 60 days of age, 12 white Pekin ducks from each treatment were challenged with a viscerotropic ND virus strain. The virus presented 1.78 intra-cerebral pathogenic index, and embryonic death time of 48 hours, with a $50 \%$ embryo-infecting dose titer of $8.15 \log _{10} / 0.1 \mathrm{~mL}$. Distilled water was used as diluent for the inoculum that was instilled by ocularnasal route, according to the Code of Federal Regulations (1993). In order to measure the pathogenicity of the NDV-challenge strain, a group of 12 Specific-Pathogen-Free (SPF) chicks were inoculated with pathogenic NDV (G5). Birds were housed in isolators with filtered air, and received feed and water ad libitum.

Virus isolation: At six, 14, 20, and 30 days postchallenge, tracheal and cloacal swabs were collected from all birds of each group to carry out virus isolation. Tracheal and cloacal swabs were placed in phosphate buffer solution (pH 7.,2) containing antibiotics. Samples were inoculated into the allantoic cavity of SPF embryonated eggs between eight and 10 days of incubation. Embryos diagnosed as positive by hemagglutination test (HA) were subsequently tested by hemagglutination inhibition test $(\mathrm{HI})$ with chicken serum containing antibodies against NDV, according to Allan \& Gough (1974), Beard (1980), and Alexander (1986). Negative samples were inoculated three times before being considered negative. Samples containing NDV were inoculated in SPF chickens, and caused $100 \%$ mortality.

\section{RESULTS AND DISCUSSION}

M ean antibody titers against NDV from white Pekin ducks are shown in Table 1. At seven days of age, none of the birds show ed maternally-derived antibodies against NDV, as breeders were not submitted to any vaccination program against this disease. At 14 days of age, antibody titers against NDV were detected in the vaccinated groups. This active immunity was induced by vaccination at seven days of age. White Pekin ducks were revaccinated at 29 days of age, and this procedure increased antibody titers against NDV up to 60 days of age, when the best serology results were observed. The low invasion capacity of the B1 strain (Hofstad, 1951) and low diffusion potential of the Ulster 2C strain (McFerran \& Nelson, 1971) may explain the moderate antibody titers detected by $\mathrm{HI}$ in vaccinated white Pekin ducks. The Test of Tukey did not demonstrate significant differences among groups vaccinated with Ulster $2 \mathrm{C}, \mathrm{B1}$, and LaSota strains. As the control group (G4) was not vaccinated, its antibody titers were null from seven to 60 days of age. The analysis of these serological results clearly shows that white Pekin ducks produce antibodies when vaccinated with live vaccines against NDV.

\footnotetext{
Table 1 - Mean antibody titers measured by $\mathrm{HI}$ test $\left(\log _{2}\right)$ of white Pekin ducks (Anas platyrhynchos) submitted to different vaccination programs against ND.

Group Vaccine Mean Antibody Titer Measured by HI Test( $\left.\log _{2}\right)$ White Pekin ducks age (days) $\begin{array}{lllllllll}7 & 14 & 21 & 28 & 35 & 42 & 49 & 56 & 60\end{array}$

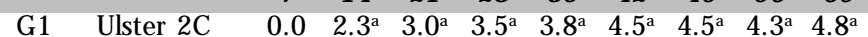
$\begin{array}{lllllllllll}G 2 & B_{1} & 0.0 & 3.0^{\mathrm{a}} & 2.8^{\mathrm{a}} & 3.8^{\mathrm{a}} & 3.5^{\mathrm{a}} & 4.0^{\mathrm{a}} & 4.5^{\mathrm{a}} & 4.3^{\mathrm{a}} & 5.0^{\mathrm{a}}\end{array}$

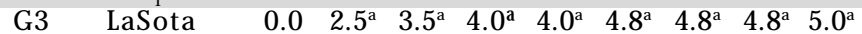

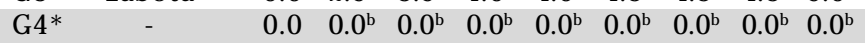

* Control group - not vaccinated against ND. 1 - Means followed by the same letter, in the same column, are not different at $5 \%$ of probability, by Tukey test $(p>0.05)$.
}

Data of white Pekin ducks challenged with velogenic NDV are shown in Table 2 . White Pekin ducks from the control group (G4) also did not show any ND signs after challenge, despite not being vaccinated against ND, which is consistent with the observations of Higgins (1971). None of the vaccinated groups presented any ND signs of after challenge. On the other hand, $100 \%$ of the SPF broilers died due to the NDV challenge, with reisolation of the virus. 


\begin{tabular}{lcccc}
\hline \multicolumn{2}{c}{ Table 2} & - Results of challenge with velogenic NDV in white Pekin ducks. \\
Group & Vaccine & Number of challenged birds & Number of birds protected against NDV challenge \\
G1 & Ulster 2C & 12 & 12 \\
G2 & B1 & 12 & 12 & 12 \\
G3 & LaSota & 12 & 12 & \\
G4 & Control & 12 & 0.0 \\
G5 & SPF chicks & 12 & \\
\hline
\end{tabular}

Table 3 shows the results of viral isolation. NDV was isolated in Pekin ducks from the control group (not vaccinated against ND - group G4) at 20 and 30 days after challenge. This confirms the sensitivity of this species to NDV, as also demonstrated by Reis \& Nóbrega (1956). These data show that white Pekin ducks are able to shed NDV 20 to 30 days after infection, which is important for the epidemiology of this disease.

\begin{tabular}{|c|c|c|c|c|c|c|c|c|c|}
\hline \multirow{3}{*}{ Group } & \multirow[t]{3}{*}{ Vaccine } & \multicolumn{8}{|c|}{ Viral isolation } \\
\hline & & \multicolumn{2}{|c|}{6 DAC } & \multicolumn{2}{|c|}{14 DAC } & \multicolumn{2}{|c|}{20 DAC } & \multicolumn{2}{|c|}{30 DAC } \\
\hline & & $T$ & C & $T$ & $\mathbf{T}$ & $\bar{C}$ & $\mathbf{T}$ & $\bar{T}$ & C \\
\hline G1 & Ulster 2C & - & - & - & - & - & - & - & - \\
\hline G2 & B1 & - & - & - & - & - & - & - & - \\
\hline G3 & LaSota & - & - & - & - & - & - & - & - \\
\hline G4 & - & - & - & - & - & + & + & + & + \\
\hline
\end{tabular}

isolation, - = negative isolation

Unfortunately, there is no information on the importance of white Pekin ducks as NDV carriers, or as to the potential risk of the dissemination of this disease by Pekin ducks to other food-producing poultry that may be raised close to Pekin duck habitats. In contrast, NDV was not isolated from groups of Pekin ducks vaccinated against NDV. This suggests that vaccination can interfere with NDV shedding in white Pekin ducks.

The conclusions of the present study are that white Pekin ducks were resistant to the development of ND clinical signs when challenged with velogenic NDV. This is important for NDV epidemiology, because white Pekin ducks can shed the virus 20 to 30 days after challenge, and vaccination against ND is essential to reduce the elimination of the virus in the field.

\section{REFERENCES}

Alexander DJ. The classification, host range and distribution of avian paramixoviruses. In: M cFerran JB; M cNulty MS, editors. Acute virus infections of poultry. Dordrecht: Matinus Nijhoff; 1986. p. 52-56.

Allan WH, Gough RE. A standart haemagglutination inhibition test for Newcastle disease. 1. A comparison of macro and micro methods. Veterinary Records 1974; 95:120-123, 1974.

Beard CW. Serologic procedures. In: Hitchner SB, Domermuth $\mathrm{CH}$, Purchase HG, Williams JE, editors. Isolation and identification of avian pathogens. Kenett Square: American Association of Avian Pathology; 1980. p. 129-135.

Code of Federal Regulations. Animal and animal products. Washington: National Arch. and Records Administr; 1993. p.818. Cunningham CH. Virologia practica. 6thed. Zaragoza: Acribia; 1971. 260p.

Higgins DA. Nine disease outbreaks associated with myxoviruses among ducks in Hong Kong. Tropical Animal Health and Production $1971 ; 3: 232-236$.

Hofstad MS. A quantative study of Newcastle disease virus in tissues of infected chickens. American Journal Veterinary Records 1951; 12:334-339.

Kaleta E, Beldauf C. Newcastle disease in free-living and pet birds. In: Alexander D, editors. Newcastle disease. Boston: Kluwer Academic Publishers; 1988. p.197-246.

M cFerran JB, Nelson R. Some properties of an avirulent Newcastle disease virus. Arch Gesamte Virusforsch 1971; 34:64-74.

Office International des Epizooties. Manual for animal disease reporting to the OIE. Paris: World Organization for Animal Health; 1996.

Paulillo AC. Estudo zootécnico e imunológico de aves de corte submetidas a diferentes programas de vacinação contra a doença de Newcastle. In: Reunião Anual da Sociedade Brasileira de Zootecnia; 1996; Fortaleza, Ceará. Brasil. p.388-390.

Reis J, Nóbrega P. Tratado de doença das aves. 2. ed. São Paulo: Edições Melhoramento; 1956. p.254. 